\title{
Psichogeninis dusulys
}

\author{
Ilona Laukienè \\ LSMU MA Psichiatrijos klinika
}

Reikšminiai žodžiai: psichogeninis dusulys, dispnèja, nuotaikos sutrikimai, nerimas.

Santrauka: Psichogeninis dusulys (psichogeninė dispnèja) - kvėpavimo funkcijų sutrikimai, sąlygoti psichinių priežasčių. Jie dažnai nediagnozuojami, nes pacientų nurodomi simptomai labai panašūs ị organinio dusulio simptomus ir nèra vienos standartizuotos metodikos, kuri padètų atlikti tikslią diagnostiką. Straipsnyje aptariamos psichogeninio dusulio priežastys, diagnostikos aspektai ir pagalbos pacientams būdai.

\section{IVADAS}

Psichogeninis dusulys (psichogeninè dispnejja) - kvėpavimo funkcijų sutrikimai, sąlygoti psichinių priežasčių. Jau 1928 m W. B. Cannon atlikti eksperimentai atskleidè, kad emocinès problemos gali neigiamai veikti kūno funkcijas. Dusulys be organinio pagrindo įvairiais laikotarpiais buvo aprašytas ịvairių autorių: $1941 \mathrm{~m}$. Paul Wood, $1943 \mathrm{~m}$. Lewis, 1950 m. Rice rašè apie kvejpavimo sutrikimus be somatinès ligos. Buvo pastebèta, kad psichogeninis komponentas gali sustiprinti dèl organinès patologijos kylanti dusuli [1]. Burns ir Howell 1969 m. aprašè 31 lètiniu bronchitu serganti pacientą, patiriantị dusuli, kuris neproporcingai stiprus. Nepaisant to, kad šis reiškinys pastebėtas gana seniai, iki dabar jis dažnai nediagnozuojamas, nes pacientų nurodomi simptomai labai panašūs i organinio dusulio simptomus ir nèra vienos standartizuotos metodikos, kuri padètų atlikti tikslią psichogeninio dusulio diagnostiką. Du žmonès, patyrę tą pačią psichotraumą, sergantys ta pačia plaučiuc ar širdies ir kraujagyslių sistemos liga, gali patirti visiškai skirtingo stiprumo ir pobūdžio dusulị, o tas pats žmogus skirtingomis aplinkybėmis gali jausti skirtingą diskomfortą kvėpuodamas [2]. Dispneja yra ir gana dažnas psichosomatinis simptomas [3]. Pacientų vartojami apibūdinimai subjektyvūs: sunkus, nemalonus, paviršutiniškas, reikalingas pastangų, negilus kvėpavimas, dusinimas, smaugimas ir pan.; jie nepadeda atskirti dusulio priežasties. Andreas von Leupoldt ir Bernhard Dahme (2007), nagrinèję psichologinius dusulio (nepriklausomai nuo jo priežasties) aspektus, teigia, jog dusulio suvokimą lemia sąveika tarp daugybès fiziologinių, socialinių, psichologinių ir aplinkos veiksnių [4]. Tai yra, kad subjektyviai patiriamas diskomfortas kvejpuojant priklauso ne tik nuo objektyviai išmatuojamų kūno fiziologijos pokyčių, bet ir nuo žmogaus asmenybès savybių (jautrumo kūno pojūčiams, polinkio ị somatizaciją, gynybinių mechanizmuc ir kt.), nuo asmens individualios patirties, jo šeimos istorijos (ar būta panašių atvejų šeimoje), net nuo kultūrinès aplinkos (kai kuriose šalyse psichikos sutrikimų turintys asmenys patiria stigmą ir tai skatina emocines problemas neigti, išgyventi jas per kūno negalavimus). Dusulio priežasties nustatymas ne tik leidžia pasirinkti tikslesni gydymą, bet ir užtikrina paciento pasitikejjimą gydytoju, didesnị saugumo jausmą, mažesnị nerimą, kas didina bendrą gydymo efektyvumą.

Straipsnio tikslas - aptarti psichogeninio dusulio ir psichogeninio komponento, atsiradusio šalia somatinès ligos, priežastis, diagnostikos aspektus ir pagalbos pacientams būdus. Analizuoti MEDLINE, Psychology and Behavioral Sciences Collection, Health Source: Nursing/Academic Edition, Health Source - Consumer Edition duomenų baziu straipsniai pagal reikšminius žodžius: Psychogenic dyspnea, Breathlessness, Sighing dyspnea, Hyperventilation.

\section{PSICHOGENINIO DUSULIO PRIEŽASTYS}

Dusulio diferencinė diagnostika literatūroje dažniausiai apima kelias dideles ligų grupes: plaučių ligas, širdies ir kraujagyslių ligas ir kita (medžiagų apykaitos, neurologiniai sutrikimai, psichogeniniai veiksniai ir pan.). Psichogeniné dispnejja dažniausiai pastebima dviem klinikiniais atvejais: panikos sutrikimai (su agorafobija ir be jos), kuriems būdingi ūminès dispnèjos simptomai, ir generalizuotas nerimo sutrikimas, kurio vienas pagrindiniu simptomų lètinè dispnèja [5]. Tačiau kartais dusulio simptomus patiria pacientai, turintys kitų psichikos ir elgesio sutrikimų: 
nuotaikos (afektinius) sutrikimus, somatoforminius sutrikimus ir kt. Psichogeninis komponentas gali sustiprinti pulmonologinių ir kardiologinių ligų sukeltą dusulị, kita vertus - dusulys gali rodyti nerimą arba kitas psichikos ir elgesio ligas. Galimas ir somatinių bei psichikos sutrikimų egzistavimas kartu.

Ryškiausiai psichogeninè dispnejja pasireiškia panikos sutrikimų atveju (TLK-10 šie sutrikimai dar vadinami epizodiniu paroksizminiu nerimu) - kvèpavimas tampa nereguliarus krūtininis vietoj ramaus pilvinio. Pradžia būna labai staigi arba laipsniška. Kaip ir kitų nerimo sutrikimų atveju, vyraujantys simptomai gali būti skirtingi kiekvienam pacientui, tačiau dažniausios trys pakopos:

1. Pirmieji/ankstyvieji panikos požymiai: galvos svaigimas/sukimasis, smarkus širdies plakimas (tachikardija), padidejęs kraujo spaudimas, nenormaliai greitas, netolygus kvėpavimas, prakaitavimas.

2. Tarpiniai: dusulys, smaugimo jausmas, pykinimas, pilvo skausmas, drebulys („krečia šaltis"), krūtinès skausmas.

3. Vèlesnieji: galūnių tirpimas ir dilgčiojimas, baimė numirti, baimė išprotèti, pakitusios realybės jausmas [3]. Jei panikos priepuolis ịvyksta specifinèje situacijoje, pvz.: minioje, autobuse, pacientas gali pradèti vengti tokių situacijų. Dažni neprognozuojami panikos priepuoliai sukelia baimę, kad priepuolis gali pasikartoti, todèl vengiama išeiti iš namų, būti vienam ar viešose vietose. Taip gali išsivystyti agorafobija - fobinis nerimo sutrikimas, kai nerimą sukelia mažiausiai dvi iš šių situacijų: minia, vieša vieta, išèjimas iš namų, kelionė vienam [6]. Dažnai panikos priepuolius patiriantiems pacientams nustatomas padidèjęs jautrumas $\mathrm{CO}_{2}$ ir nerimo sutrikimai šeimų istorijose.

Generalizuotas nerimo sutrikimas pasireiškia nuolatiniu nerimu, kuris trunka ilgai - kelias savaites ar ménesius iš eilès. Šalia blogos nuojautos, dèmesio koncentracijos sunkumų, raumenu įtampos, būna vegetacinis (autonominis) hiperaktyvumas: galvos svaigimas, prakaitavimas, tachikardija, silpnumas, burnos džiūvimas ir padažnejjęs kvėpavimas [6].

Afektiniai sutrikimai - lengvos, vidutinès ir sunkios depresijos epizodai, taip pat ivvairaus sunkumo pasikartojančios depresijos epizodai gali pasireikšti kartu su somatiniu sindromu. Pacientų nusiskundimai labai ịvairūs: galvos skausmai ir svaigimas, raumenu itampa, silpnumas, taip pat ir kvejpavimo sutrikimai [7]. Galimi depresijos atvejai, kai pirmiausia išryškèja ne nuotaikos sutrikimai, o somatiniai simptomai, pavyzdžiui, vazomotorinis alerginis variantas (sunku kvejpuoti, užgula nosị, degina nosies gleivinę, pakinta balso tembras) arba pseudoastmos variantas (sutrinka kvèpavimo ritmas, gilumas, dažnis). Dažniausiai tokie pacientai neakcentuoja blogos nuotaikos, o jei ją ir pripažista, tai aiškina somatiniais negalavimais („kokia gali būti nuotaika, kai sergu“). Vieni autoriai šį reiškinį sieja su aleksitimija (negebejjimu išreikšti savo emocijų ir jausmų) ir išstūmimo, neigimo, somatizacijos tendencijomis, kiti su kultūrinèmis tradicijomis, kurios „neleidžia“ reikšti jausmų arba stigmatizuoja asmenis, turinčius psichikos sutrikimus [8].

Disociaciniai (konversiniai) sutrikimai kyla dèl psichiką traumuojančių ịvykių, neišsprendžiamų arba nepakeliamų problemų ar tarpasmeninių santykių sutrikimų; jų atsiradimo laikas glaudžiai susijęs su traumavusia patirtimi. Jie išnyksta per kelias savaites ar mėnesius, jei priežastis buvo konkretus ìvykis. Esant santykių problemoms ar neišsprendžiamoms situacijoms, jie gali užsitęsti kelis metus ir tada labai sunkiai gydomi. Pacientai patiria pačius ìvairiausius simptomus ir jais aiškina bet kokias problemas, kurias pripažista patys, o realius sunkumus, kurie akivaizdūs aplinkiniams, neigia [6]. Nors dažniausi sutrikimai yra atminties praradimas, jutimų ir judesių sutrikimai, stuporo simptomai, traukuliai, tačiau galimi ir kiti nusiskundimai, įskaitant kvejpavimo sutrikimus. Kenneth R. Kaufman su kolegomis 2007 m. pateike analizę atvejo, kai neįsisąmoninto psichologinio skausmo fizinè išraiška buvo susijusi su gedejimu ir liūdesiu [9]. Tarp 6 ir 8 gyvenimo metų berniukas, kurio atvejis analizuojamas straipsnyje, neteko keturių giminaičių ir mylimo šuns, o, praejus metams po paskutinès netekties, kartu su tèvais pateko ị dramatišką eismo įvykị. Po medicininès apžiūros, neradus reikšmingų sužeidimų, berniukas išvyko ị namus; jo tètis turèjo likti ligoninèje dèl patirtų traumų. Berniuko kvépavimas buvo normalus, kol paguldytas ị lovą miegoti jis pajuto ūmų dusuli. Disociacinis sutrikimas buvo diagnozuotas atmetus organines priežastis ir surinkus anamnezę, o praejjo po to, kai berniukui buvo atlikta krūtinès rentgenograma ir parodyta, kad nèra lūžusių šonkaulių bei paaiškintos tikrosios dusulio priežastys. Rentgenograma buvo atlikta dèl psichologinių priežasčių (nebuvo jokių įtarimų, kad krūtinès ląsta gali būti pažeista) [9]. Šis psichogeniniu dusuliu pasireiškęs disociacinio sutrikimo atvejis iliustruoja ir vieną iš pagalbos tokiems pacientams būdų - greitą intervenciją, informacijos suteikimą, priežasčiuc ir pasekmių paaiškinimą.

Somatoforminiai sutrikimai (kaip antai somatizacinis sutrikimas, hipochondrija, somatoforminè vegetacinè disfunkcija) pasireiškia nuolatiniais somatiniais simptomais, dèl kurių reikalaujama medicininio ištyrimo, nepaisant pakartotinių neigiamų tyrimų rezultatų bei gydytojų itikinèjimų, kad simptomai neturi somatinio pagrindo. Pacientai kategoriškai atsisako kalbèti apie galimas psichologines sutrikimų priežastis ar juos susieti su esamais socialinio ir šeimyninio funkcionavimo sunkumais [6]. Šių sutrikimų atveju dažnai pastebimas ir demesio siekiantis elgesys. Psichiatrų konsultacijos dažniausiai vengiama.

Psichogeninis dusulio komponentas sergant kvėpavimo takų, plaučių ir širdies bei kraujagyslių sistemos ligomis gana plačiai aptariamas mokslo literatūroje ir dažniausiai siejamas su nerimu, panika, depresija, išprovokuota pagrindinès ligos $[4,10,11,12]$ bei tam tikromis asmenybès savybėmis [13]. Lètinėmis kvėpavimo takų ligomis (ypač lètine obstrukcine plaučių liga (LOPL) ir astma) sergantiems pacientams depresija nustatoma apie keturis kartus dažniau nei kontrolinèje grupejje [12]. Depresijos ir nerimo sutrikimus turinčių pacientų dusulio simptomai yra dažnesni ir stipresni nei tų, kurie minètų sutrikimų neturi [13]. Tačiau tokie pacientai labai retai ieško pagalbos. Galimai nenoras pripažinti emocines problemas ir kreiptis i psichiatrą ar psichologą sąlygoja didesni dėmesio sutelkimą ties somatiniais nusiskundimais. Negydoma depresija 
ir nerimas tarp pacientų, sergančių LOPL ir astma, yra labiau taisyklè nei išimtis $[11,12]$. Afektiniai sutrikimai ne tik sunkina pagrindinès ligos simptomus, bet neigiamai veikia bendrą paciento gyvenimo kokybę, sąlygoja bejègiškumo jausmą. Tokie pacientai neadekvačiai sumažina savo fizinį aktyvumą, turi ịvairių baimių, suvokia save kaip neiggalius [10]. Autoriai, nagrinėję LOPL sergančių pacientuc asmenybès profilius ir psichologinius gynybos mechanizmus, nurodo, jog LOPL ligoniu asmenybès struktūra skiriasi nuo sveikų asmenų. Jie kur kas dažniau naudoja neigimo ir somatizacijos gynybas, o asmenybė dažniau pasižymi neurotizmu, pesimizmu ir pasyvumu [13].

\section{PSICHOGENINIO DUSULIO DIAGNOSTIKA}

Dauguma autorių sutaria, kad diagnozuoti psichogeninị dusulị yra sunku. Dažniausiai siūloma kruopščiai ir detaliai išsiaiškinti paciento istoriją.

B. Niggemann [1] pateikia klausimus, kurie gali padèti surinkti reikalingą informaciją apie pacientą ir galimus psichogeninio dusulio požymius:

1. Kuо tiksliau apibūdinkite savo simptomus įkvèpimo, iškvepimo metu; ar jaučiamas skausmas, koks dusulio stiprumas, pobūdis ir pan. Psichogeninis dusulys paprastai apibūdinamas visada tais pačiais nekintančiais žodžiais, kas nebūdinga organiniams sutrikimams. Galimi atipiniai psichogeninès dispnejos apibūdinimai, pvz.: „gumulas gerklèje“, „kaip gyvatè apsivijusi kaklą" ir pan.

2. Ar koks nors garsas - duslus, šaižus - yra girdimas kvépavimo sutrikimo metu? Ar aplinkiniai ji girdi? Paprastai aplinkiniai negirdi jokio garso, nebent kartu pasireikštų balso stygų disfunkcija.

3. Ar dusulys pasireiškia tuo pačiu paros metu: rytais, vakarais, kažkuriuo konkrečiu paros metu? Ar galima stebeti paros ritma? Psichogeninis dusulys neturi "ritmo" - gali pasireikšti bet kada.

4. Ar dusulys pasireiškia jums miegant? Ar pabundate nakti dèl dusulio? Psichogeninis dusulys "neprikelia“ miegančių pacientų. Klausimas: „Ar büna simptomai nakti??" nèra tikslus, nes psichogeninis dusulys galimas ir nakties metu, bet tik tada, kai pacientas dar nemiega.

5. Kokia buvo dusulio pradžia? Ar jis prasidèjo po kvépavimo taku infekcijos ar po kokio kito konkretaus jvykio? Dažnai psichogeninis dusulys pasireiškia po iprastinio peršalimo ar bronchito. Pacientui pasveikus, kvépavimo sunkumai pasilieka jau be aiškios priežasties. Kitos priežastys - psichiką traumuojantys ivykiai (netektis, skyrybos ir pan.).

6. Kas dažniausia išprovokuoja dusuli? Ar galima susieti kvépavimo problemas su konkrečia situacija? Fizinis krūvis gali sustiprinti tiek psichogeninị dusulị, tiek organinị, tačiau psichosocialinis stresas arba jokio trigerio nebuvimas rodo psichogeninę dispnejos priežastį.

7. Ar simptomai pasireiškia esant ramybès būklès, ilsintis? Ar būna dusulio simptomai žiūrint ìdomu filma, isitrau- kus $\dot{i}$ mégstama veiklą? Psichogeninis dusulys dažniau pasireiškia ramybès, neveiklumo metu ir jo simptomu nebūna sukoncentravus dèmesị ì mėgstamą veiklą.

8. Ar galite sportuoti? Ar fiziniu pratimu metu būna kvépavimo trukdžių? Fizinis aktyvumas labai retais atvejais sustiprina psichogeninio dusulio simptomus, tačiau gali būti, kad pacientas atsisako atlikti fizinius pratimus, baimindamasis, kad jų metu "gali pritrūkti oro“.

9. Kiek laiko trunka dusulio epizodai? Kiek minimaliai, maksimaliai, vidutiniškai sekundžiu, minučiu, valandu tęsiasi kvèpavimo sunkumai? Kaip pavyksta juos sustabdyti, kaip greitai galite grižzti i normaliq būse$n a$ ? Psichogeninio dusulio epizodų trukmė labai įvairuoja. Tarkime, astmos simptomai praeina per $10-20$ min., o psichogeninio dusulio priepuolis gali baigtis jau po keleto minučių.

10. Ar tuo metu, kai jaučiate kvèpavimo nepakankamuma, galite kalbeti? Esant organinei dispnèjai, kalba sutrinka, pacientui reikalingos pauzès, kad jis galètu ¡kvėpti; psichogeninis dusulys netrukdo kalbèti, pacientu tartis ir balsas nepakinta.

11. Kas dèl jūsų simptomų kenčia, nerimauja labiau jūs ar jūsų artimieji? Paprastai esant psichogeniniam dusuliui paciento kančia yra mažesnè nei jo artimųjų. Kartais aplinkinius paciento simptomai gali net erzinti, sukelti pykti.

12. Kokioje kūno vietoje jūs jaučiate sunkuma kvépuojant? Paprašykite paciento kuo tiksliau pirštu parodyti vietą, kurioje jaučiamas diskomfortas dusulio metu. Esant psichogeniniam dusuliui, pacientai rodo ties gerkle, o somatinių ligų atveju žemiau - ties krūtinès ląsta.

13. Ar jus kada nors vargino nerviniai tikai, pvz., nevalingi akiu voku trūkčiojimai, mirksejjimas, kosčiojimas ir pan.? Teigiamas atsakymas padidina tikimybę, kad dusulys psichogeninès kilmès.

14. Ar kada nors anksčiau vartojote vaistus kvépavimo sutrikimams gydyti? Koks buvo ju poveikis? Ar jie sumažino simptomus? Kiek? Jokie vaistai, skirti gydyti organiniam dusuliui, nepadeda sumažinti psichogeninio dusulio; galimas tik menkas trumpalaikis placebo efektas.

Kaip papildoma priemonė gali būti naudojami nerimo ir depresijos klausimynai ịvertinti nuotaikos sutrikimų tikimybę [14].

T. R. Sahasrabudhe išskiria penkis apibendrintus kriterijus, kurie skiria psichogeninị dusuli nuo organinio:

1. Simptomų nebuvimas miego metu.

2. Psichiką traumuojantys ịvykiai ar situacija.

3. Tipinių aplinkos trigerių nebuvimas.

4. Simptomai dažniau pasireiškia ilsintis.

5. Dusulio metu diagnostinių tyrimų rezultatai normalūs [3]. Yra autorių, siūlančių trumpinti diagnostinius tyrimus. Jų nuomone, jei pacientas skundžiasi lètine dispnèja, bet nèra periodišku pastangu i ikvèpti giliau, kad prisipildytų plaučiai, ir îprastiniai tyrimai nerodo organinès priežasties, vadinasi, tai nerimo dispnejja ir tolesnès brangios diagnostinès procedūros neturètų būti atliekamos (Weiner D.; Weiner P.; Beckerman M., 2014) [15]. 


\section{PAGALBA PACIENTAMS, PATIRIANTIEMS PSICHOGENINI DUSULI}

Ittarus, jog kvẻpavimo sutrikimų priežastis yra psichogeninè, arba matant, kad psichogeninès priežastys sustiprina somatinès ligos simptomus, pacientą būtina siųsti psichiatro ar psichologo konsultacijos. Šie specialistai gali patikslinti psichikos ir elgesio sutrikimą naudodami psichodiagnostinius metodus ir parinkti adekvačią farmakoterapiją ir (ar) psichoterapiją.

Tyrimai rodo, jog efektyviausi yra kognityvinès elgesio terapijos (KET) metodai [10]. Ši terapija paremta teorija, kuri akcentuoja glaudų ryši tarp asmens aplinkos, minčių, fizinių reakcijų, nuotaikos ir elgesio. Keičiant vieną iš šių penkių komponentų, automatiškai keičiasi kiti, pvz.: keičiant mintis, galima pakeisti ir fizines reakcijas. Todèl pirmiausia siekiama pacientą informuoti: jam suprantama kalba išaiškinti, kas vyksta jo organizme, kad jis adekvačiau suvoktu galimą pavojų (nekatastrofizuotų) ir savo galimybes tą pavojų íveikti. Tai vadinama kognityviąja pertvarka - vienas iš efektyviausių būdų gydant panikos sutrikimus.

Kita priemoné - relaksacija: fizini ir psichini atsipalaidavimą akcentuojantys metodai. Jų pacientas gali išmokti ir taikyti pats namuose. Dažniausiai taikomi 4 rūšių pratimai. Progresyvus raumenu atpalaidavimas - tai metodas, kai pagrindinès raumenu grupès pakaitomis ittempiamos ir atpalaiduojamos (itempiama 5 sekundes ir atpalaiduojama 10 sekundžių). Atsipalaidavus fiziškai sumažèja nerimas. Itin tinkami metodai psichogeniniam dusuliui kontroliuoti valdomo kvėpavimo pratimai. Pacientą siekiama išmokyti bent keturias minutes reguliuoti savo kvėpavimą, nes maždaug tiek laiko reikia deguonies ir anglies dvideginio pusiausvyrai grąžinti. Dar vienas būdas, mažinantis nerimą ir padedantis atsipalaiduoti, - vaizdinių kūrimo metodai: ịsivaizdavimas malonių, ramių vaizdinių. Vaizduotè tuo labiau padeda atsipalaiduoti, kuo daugiau pojūčiu įtraukiama ì kuriamą vaizdinị. Démesio atitraukimas veiksmingas tuo, kad nukreipia dèmesi nuo nerimą palaikančių minčių ir fizinių pojūčių. Svarbu bent kelias minutes išlaikyti atitrauktą demesị ir tikètis, kad nerimas sumažès.

Paprastai išbandoma visų rūšių relaksacija ir pasirenkama ta, kuri veiksmingiausia konkrečiam pacientui.

\section{APIBENDRINIMAS}

Psichogeninis dusulys (kvėpavimo funkcijų sutrikimai, sąlygoti psichinių priežasčių) dažnai nediagnozuojamas, nes pacientų nurodomi simptomai labai panašūs ị organinio dusulio simptomus ir nèra vienos standartizuotos metodikos, kuri padètų atlikti tikslią diagnostiką. Psichogeninè dispnèja dažniausiai pasitaiko nuotaikos sutrikimų bei neurozinių, stresinių ir somatoforminių sutrikimų atvejais. Pulmonologinių ir kardiologinių ligų sukeltą dusuli gali sustiprinti psichogeninis komponentas. Diagnozuoti psichogenini dusuli padeda kruopščiai surinkta paciento istorija. Ittarus, jog kvėpavimo sutrikimų priežastis yra psichogeninè, arba matant, kad psichogeninès priežastys sustiprina somatinès ligos simptomus, pacientą būtina siųsti psichiatro ar psichologo konsultacijos. Šie specialistai naudodami psichodiagnostinius metodus gali patikslinti diagnozę ir parinkti adekvačią farmakoterapiją ir (ar) psichoterapiją.

\section{PSYCHOGENIC DYSPNEA}

ILONA LAUKIENE

DEPARTMENT OF PSYCHIATRY LITHUANIAN UNIVERSITY OF HEALTH SCIENCES

Keywords: psychogenic breathlessness, dyspnea, mood disorders, anxiety. Summary. Psychogenic dyspnea - breathing dysfunction caused by mental reasons. This dysfunctions often are undiagnosed, because patients' outlined symptoms are very similar to symptoms of organic dyspnea. Also, there is not a single standardized method that would help to make an accurate diagnosis. The article discusses the causes of psychogenic dyspnea, its diagnostic aspects and patient care methods.

\section{LITERATŪRA}

1. Niggemann B. How to Diagnose Psychogenic and Functional Breathing Disorders in Children and Adolescents. Pediatr Allergy Immunol. 2010, 21: 895-899.

2. Valius L. Lètinis dusulys šeimos gydytojo praktikoje. Lietuvos bendrosios praktikos gydytojas. 2008, XII (9).

3. Sahasrabudhe TR. Psychogenic Dyspnea. Med J DY Patil Univ [serial online] 2013 [cited 2015 Jul 28];6:14-8. Available from: http://www.mjdrdypu.org/ text.asp?2013/6/1/14/108627.

4. Von Leupoldt A, Dahme B. Psychological Aspects in the Perception of Dyspnea in Obstructive Pulmonary Diseases. Respiratory Medicine. 04/2007. 101(3):411-22.

5. Cottraux JA. Clinical Trap: Acute and Chronic Ppsychogenic Dyspnea. Rev Prat. 2009, 59: 615-618.

6. Tarptautinès statistinès ligy ir sveikatos sutrikimy klasifikacijos dešimtasis pataisytas ir papildytas leidimas "Sisteminis ligu sąrašas (Australijos modifikacija, TLK-10-AM)“, 2011. http://ebook.vlk.lt/e.vadovas/index.jsp

7. Jacobsen LN, Lassen IS, Friis P, Videbech P, Licht RW. Bodily symptoms in moderate and severe depression. Nord J Psychiatry. 2006, 60:294-298.

8. Simon GE, VonKorff $M$, Piccinell $M$, Fullerto $C$, Ormel J. An International Study of the Relation between Somatic Symptoms and Depression. N Engl J Med. 1999, 341:1329-1335.

9. Kaufman KR, Endres JK, Kaufman ND. Psychogenic Dyspnea and Therapeutic Chest Radiograph. Death Stud. 2007, 31(4):373-81.

10. Smoller JW, Pollack MH, Otto MW, Rosenbaum JF, Kradin RL. Panic Anxiety, Dyspnea, and Respiratory Disease. Theoretical and Clinical Considerations. Am J Respir Crit Care Med. 1996, 154: 6-17. http://www.researchgate. net/profile/Jordan_Smoller/publication/14520461_Panic anxiety dyspnea_and_respiratory_disease._Theoretical_and_clinical_considerations/ links/02bfe50dd3513b94a2000000.pdf

11. Lavietes MH, Matta J, Tiersky LA, Natelson BH, Bielory L, Cherniack NS. The Perception of Dyspnea in Patients with Mild Asthma. Chest. 2001, 120:409-415.

12. Kunik ME, Roundy K, Veazey $C$, Souchek J, Richardson P, Wray NP, Stanley MA. Surprisingly High Prevalence of Anxiety and Depression in Chronic Breathing. Disorders Chest. 2005, 127(4):1205-1211.

13. Albuquerque SC, Eduardo R. Carvalho ER, Lopes RS, Marques HS, Mace^do DS, Pereira ED, Hyphantis TN, Carvalho AF. Ego defense mechanisms in COPD: impact on health-related quality of life and dyspnoea severity. Qual Life Res. 2011, 20:1401-1410.

14. Han JN, Zhu YJ, Li SW, Luo DM, Hu Z, Van Diest I, De Peuter S, Van de Woestijne KP, Van den Bergh O. Medically unexplained dyspnea: psychophysiological characteristics and role of breathing therapy. Chin Med J. 2004, 117(1):6-13.

15. Weiner D, Weiner P, Beckerman M. Anxiety dyspnea, Harefuah . 2014, 153 (3-4): 147-50, 240. 